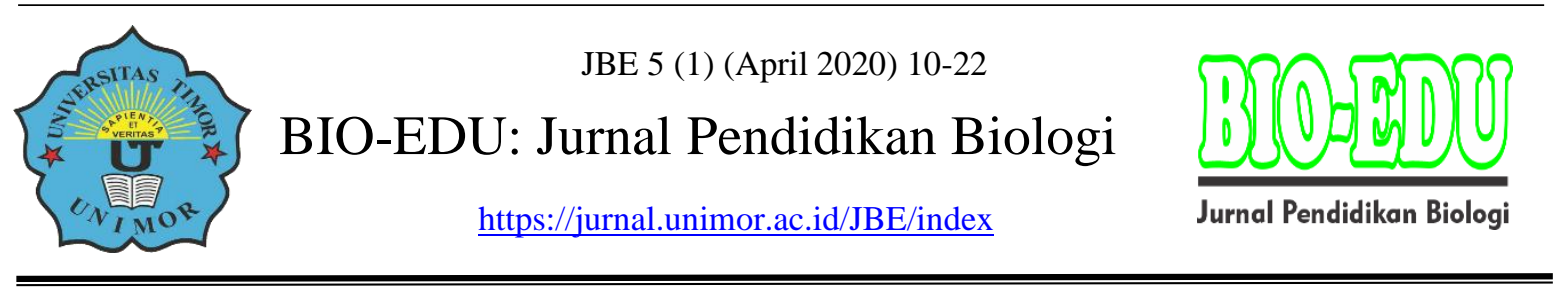

\title{
Identifikasi Potensi Materi Ajar Invertebrata Di Area Pantai Kecamatan Serasan Pada Materi Pelajaran IPA
}

\author{
Weldi \\ Program Studi Pendidikan Biologi, Universitas Muhamadiyah Pontianak \\ Email: abrahamweldy@gmail.com
}

DOI: https://DOI 10.32938/jbe.v5i1.492

\begin{abstract}
Abstrak
Pantai di area Kecamatan Serasan merupakan salah satu pantai yang memiliki potensi lokal yang kurang dimanfaatkan. Oleh karena itu perlu dilakukan penelitian yang bertujuan untuk memberikan informasi kepada guru tentang lokasi yang dapat dijadikan tempat proses pembelajaran di luar kelas. Penelitian ini menggunakan metode deskriptif kualitatif dan eksplorasi. Teknik pengumpulan data menggunakan observasi, identifikasi, wawancara dan dokumentasi. Hasil penelitian potensi hewan Invertebrata di area Pantai Kecamatan Serasan berupa keanekaragaman jenis hewan Invertebrata pada filum Molusca, Arthropoda, Coelenterata, dan Echinodermata. Potensi lokal hewan Invertebrata di area Pantai Kecamatan Serasan sesuai dengan tujuan pembelajaran materi Invertebrata (Animalia) pada kelas X yaitu Menentukan Ciri-ciri Umum Hewan Invertebrata (lapisan tubuh, rongga tubuh, simetris tubuh, dan reproduksi) ; Menentukan Daur Hidup Invertebrata ; Menentukan Klasifikasi Invertebrata ; menentukan Peranan Invertebrata (menjelaskan peranan hewan bagi kehidupan). Potensi lokal hewan Inveretebrata di area Pantai Kecamatan Serasan berpotensi sebagai tempat proses pembelajaran Biologi SMA.
\end{abstract}

Kata kunci: Hewan Invertebrata, Materi Ajar, Pantai Di Area Kecamatan Serasan

\begin{abstract}
The beach in the Serasan sub-district is one of the beaches that has local potential that is underutilized. Therefore it is necessary to conduct research that is intended to provide information to teachers about the location that can be done outside the classroom learning process. This research uses descriptive qualitative and exploration methods. The technique of collecting data uses observation, collection, interviews and documentation. The results of the study of the potential of invertebrate animals in the Coastal District of Serasan District consisted of invertebrate animals in the phylum Molluscs, Arthropods, Coelenterata, and Echinoderms. The local potential of Invertebrate animals in the Coastal District of Serasan District is in accordance with the learning objectives of Invertebrate (Animalia) material in class X, namely Determining the General Characteristics of Invertebrate Animals (body lining, body cavity, body symmetry, and replacement); Determine the life cycle of invertebrates; Determine the classification of invertebrates; determine the role of invertebrates (explain the role of animals for life). The local potential of Inveretebrata animals in the Pantai District of Serasan District as a place for the Biology High School learning process.
\end{abstract}

Keywords: Invertebrate Animals, Teaching Material, Beaches In The Serasan Sub-District 


\section{PENDAHULUAN}

Potensi lokal adalah kekayaan alam, budaya, dan SDM pada suatu daerah. Potensi alam di suatu daerah bergantung pada kondisi geografis, iklim, dan bentang alam daerah tersebut (Aditiawati, 2016: 59). Potensi lokal memberikan kesempatan bagi guru untuk memudahkan dalam mengaitkan pengetahuan baru yang akan disampaikan kepada siswa (Lestari 2014: 129).

Menurut Lestari (2014: 129) Potensi lokal dapat dikembangkan dan digunakan sebagai sumber belajar, dengan memanfaatkan potensi yang ada sebagai sumber permasalahan, ide, atau gagasan yang dapat digunakan untuk kepentingan belajar dan mendukung proses pembelajaran biologi. Menurut Sri Wahyuni (2016:455-460) budaya lokal yang berkembang di masyarakat dipadukan dengan kurikulum sekolah dapat menghasilkan pembelajaran yang kontekstual. Kurikulum yang saat ini digagas oleh pemerintah, yaitu kurikulum 2013, menekankan kepada pembelajaran yang berbasis kepada aplikasi dalam kehidupan sehari-hari. Pembelajaran biologi sebagai salah satu bagian dari pendidikan memiliki potensi besar dalam memanfaatkan lingkungan sebagai sumber belajar (Situmorang, 2016: 51).

Pulau Serasan mempunyai luas terumbu karang $213.821\left(\mathrm{~km}^{2}\right)$ dengan karang mati $95.498\left(\mathrm{~km}^{2}\right)$ sebanyak 44.66\%, karang hidup $118.323\left(\mathrm{~km}^{2}\right)$ sebanyak 55.34\%. Kemudian luas dan sebaran sedimen/pasir laut, dengan luas sebaran sedimen $0.4690\left(\mathrm{~km}^{2}\right)$ sebanyak $5.78 \%$ dari luas kecematan $718.700\left(\mathrm{~km}^{2}\right)$ sebanyak 0.65\%, menjadikan Pulau Serasan terluas sebaran sedimen atau pasir laut didaerah Natuna dan terdapat banyak pantai yang berpotensi. Didukung oleh letaknya yang jauh dari penyebab kerusakan lingkungan laut seperti: lalu lintas pelayaran, pembangunan yang berskala besar dan potensi senyawa kimia yang merusak perairan, menyebabkan kepulauan ini kaya akan beraneka ragam jenis Biota Laut (Pigawati, 2005:229-236). Dalam hal ini pentingnya mengangkat potensi lokal yang ada di Pulau Serasan, dikarenakan dari hasil observasi awal dibeberapa daerah pantai tersebut banyak ditemukan hewan invertebrta yang dapat dijadikan materi biologi di SMA (2018).

Berdasarkan hasil wawancara kepada Kepala Kantor Petugas Dinas Perikanan, Kecamatan Serasan banyak menyimpan potensi lokal, karena daerah ini dikelilingi oleh pantai bagus untuk pertumbuhan dan perkembangan hewan di dalamnya. Menurut Kepala Koordinator UKSPF dan guru biologi potensi lokal belum dimanfaatkan secara optimal dalam kegiatan pembelajaran biologi, sedangkan pemanfaatan potensi lokal di daerah tersendiri merupakan salah satu karakteristik dalam pengembangan kurikulum, dan guru belum pernah mengajak siswa ke area pantai tersebut.

Menurut Permendikbud No. 103 tahun 2014 diharapkan setiap guru biologi dapat menginisiasi pembelajaran biologi yang bersifat kontekstual. Guru dapat memperhatikan segala potensi lokal yang terdapat di sekolah sebagai wadah sumber belajar (Situmorang, 2016: 52). Sumber belajar adalah bahan-bahan yang dimanfaatkan dan diperlukan dalam proses pembelajaran, yang dapat berupa buku teks, media cetak, media elektronik, narasumber, lingkungan sekitar, dan sebagainya yang tersedia di sekitar lingkungan belajar yang berfungsi untuk membantu optimalisasi hasil belajar (Purnomo, 2013: 60). 
Hal ini sejalan dengan permasalahan yang ditemukan di lapangan, berdasarkan hasil wawancara terhadap 2 guru mata pelajaran Biologi di SMAN 1 Serasan, SMAN 1 Serasan Timur diperoleh informasi bahwa guru belum pernah memanfaatkan Pantai sebagai informasi sumber belajar Biologi di sekolah.

Maka penelitian ini bertujuan untuk memberikan informasi mengenai potensi lokal yang terdapat di area Pantai Kecamatan Serasan sebagai tempat proses pembelajaran biologi guna membantu guru menerapkan pembelajaran kontekstual dalam proses pembelajaran di sekolah.

\section{METODE}

Penelitian dilaksanakan Bulan November 2019 di area Pantai Kecamatan Serasan. Metode penelitian yang digunakan dalam penelitian ini adalah metode deskriptif dan metode eksplorasi untuk memberikan paparan atau gambaran secara terperinci mengenai potensi lokal yang terdapat di Pantai Kecamatan Serasan yang dapat digunakan sebagai tempat proses pembelajaran pada materi invertebrata bagi peserta didik serta guru yang mengajar di sekolah, dimana akan dilaksanakan di Pantai Tanjung Setelung dan Pantai Tanjung Balau, Kelurahan Pelimpak, Kecamatan Serasan, Kabupaten Natuna. Penelitian ini menggunakan pendekatan kualitatif. Pendekatan kualitatif dalam penelitian ini menghasilkan data deskriptif berupa tulisan naratif mengenai potensi lokal yang terdapat di Pantai Kecamatan Serasan yang dapat dimanfaatkan dan dikaitkan dengan materi biologi SMA di sekolah sebagai tempat proses pembelajaran bagi siswa serta guru yang mengajar di sekolah. Dalam metode ini, pendeskripsian yang dilakukan dengan cara menganalisis potensi lokal yang terdapat di Pantai Kecamatan Serasan kemudian menyesuaikannya dengan kompetensi dasar pada materi invertebrata kelas X. Teknik Pemeriksaan Keabsahan Data berupa data yang didapatkan dari berbagai sumber seperti buku-buku yang terkait hewan Invertebrata, Koordinator UKSPF serta guru-guru yang mengampu pelajaran IPA.

\section{HASIL DAN PEMBAHASAN}

\section{Hasil}

\subsection{Hasil Observasi}

Hasil observasi merupakan hasil dari pengamatan langsung diarea Pantai Tanjung Setelung dan Tanjung Balau. Dari hasil pengamatan terdapat berbagai jenis hewan invertebrata yang ditemui di daerah tersebut. Pengamatan ini dilakukan dengan cara membentang tali berukuran $5 \mathrm{~m}$ x $50 \mathrm{~m}$ di area Pantai, dan melakukan penelitian dan pengamatan dengan mengambil gambar objek yang ditemui dan dicatat. Adapun beberapa jenis-jenis spesies invertebrata yang ditemui yaitu; 
Tabel 4.1 Jumlah Jenis Hewan Yang Ditemukan Di Area Pantai Kecamatan Serasan

\begin{tabular}{|c|c|c|c|c|c|c|}
\hline No & NamaTempat & Gambar & $\begin{array}{c}\text { Jumlah } \\
\text { Yang } \\
\text { Ditemui }\end{array}$ & Filum & Class & Genus \\
\hline \multirow[t]{12}{*}{1} & $\begin{array}{c}\text { PantaiTanjung } \\
\text { Balau }\end{array}$ & & 11 & Molusca & Bivalvia & Meretrix \\
\hline & & & 3 & Arthropoda & Crustacea & Coenobita \\
\hline & & & & & & Turbo \\
\hline & & & 8 & Molusca & Gastropoda & \\
\hline & & & & & & Gandalfus \\
\hline & & & 1 & Arthropoda & Crustacea & \\
\hline & & & & & & Necora \\
\hline & & & 9 & Arthropoda & Crustacea & \\
\hline & & & & & & Portonus \\
\hline & & & 6 & Arthropoda & Crustacea & \\
\hline & & & & & & Turbo \\
\hline & & & 2 & Molusca & Gastropoda & \\
\hline
\end{tabular}




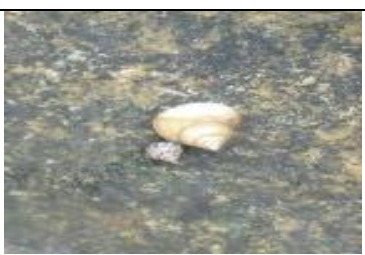

Molusca Bivalvia

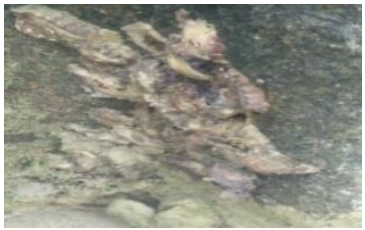

13

Molusca Gastropod

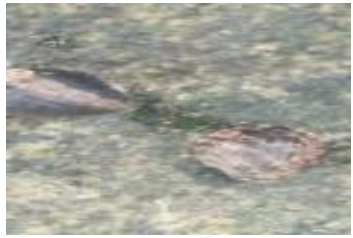

Hemigrap

sus

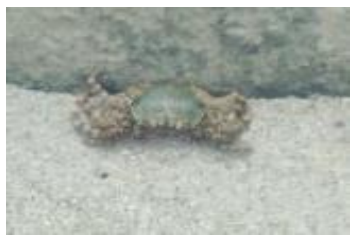

5

Anthrophoda

Crustacea

Ceriantha

ria

1

Colenterata

Anthozoa

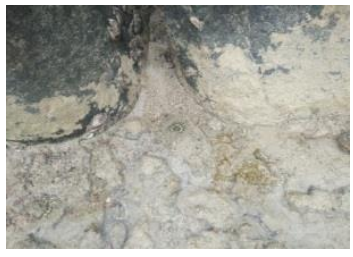

Anadara

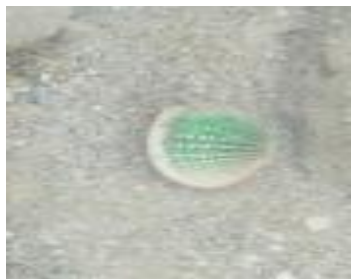

1

Molusca

Bivalvia

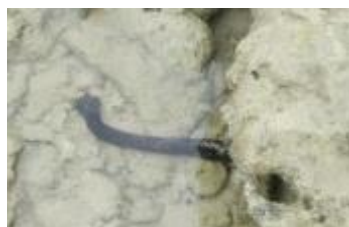

4

Echinodermata

Holothuroid

ea

Harpago

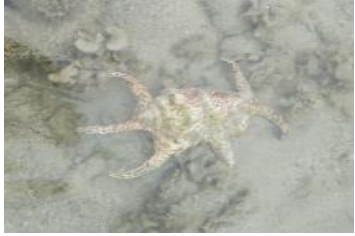

Trochus

Molusca

Gastropoda

Turbo

14|Weldi/JBE 5( 1 ) (A pril 2020) 10 - 22 


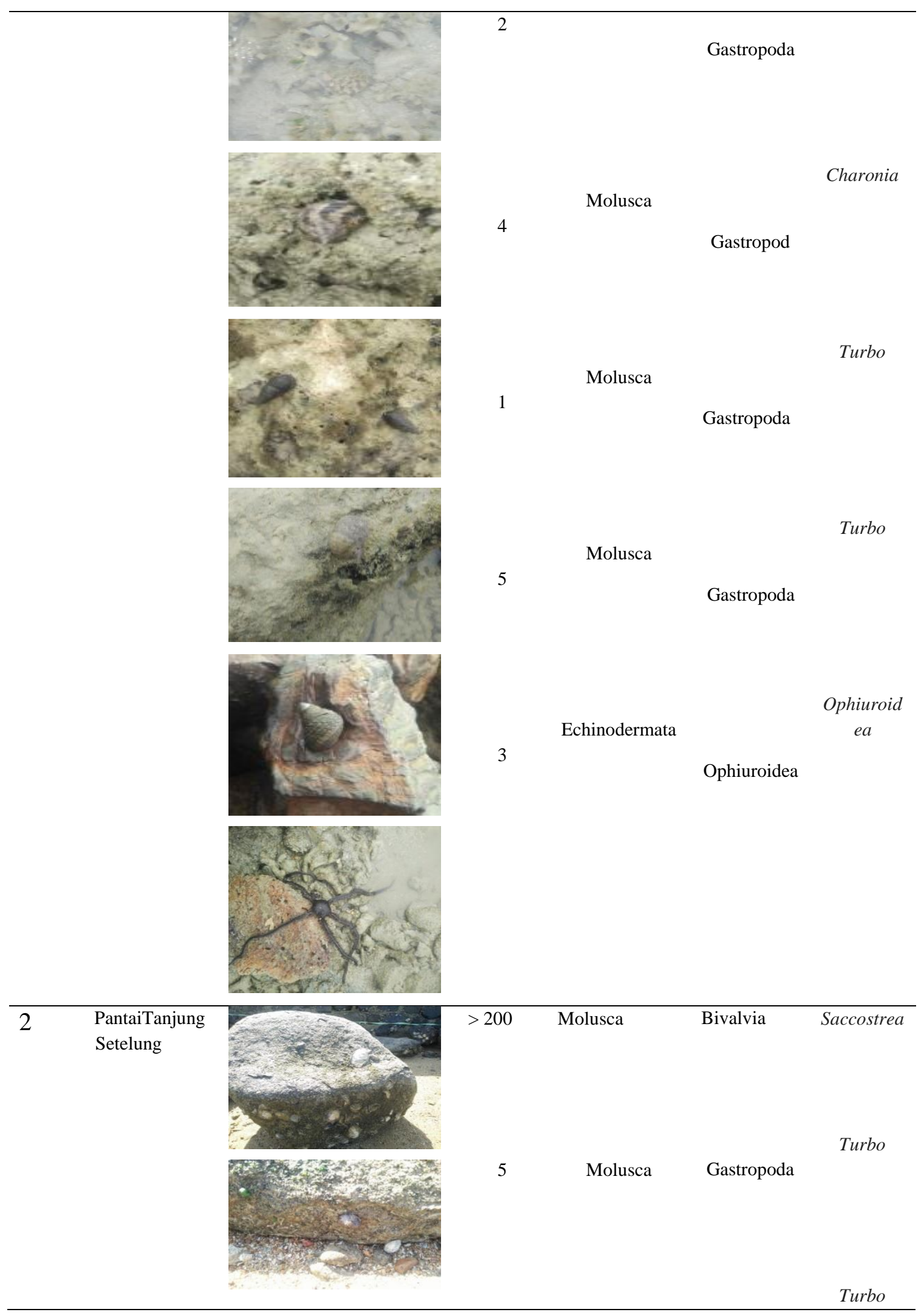

15| We ldi/JBE 5(1) (A pril 2020) $10-22$ 


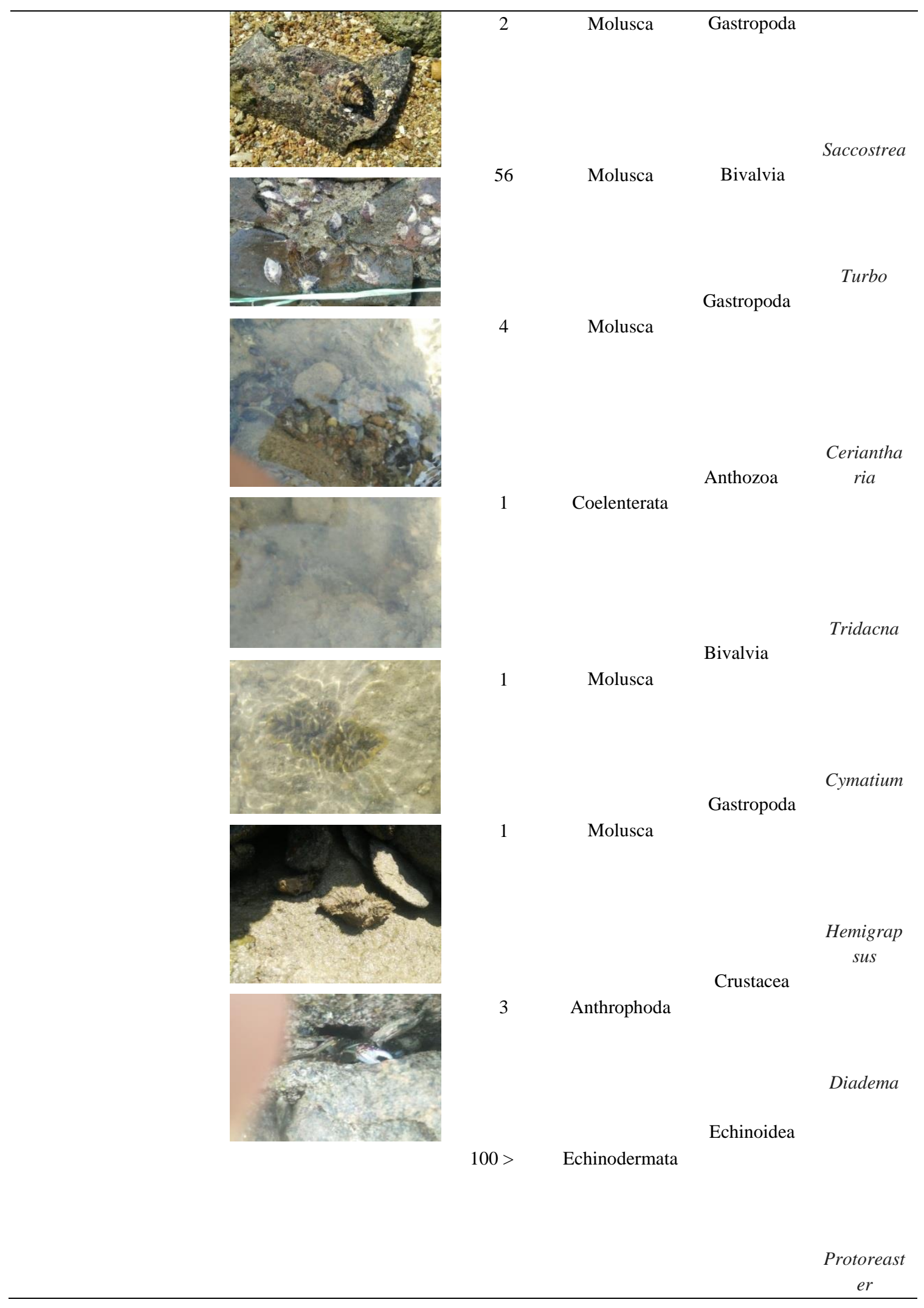

16| We ldi/JBE 5(1) (A pril 2020) $10-22$ 


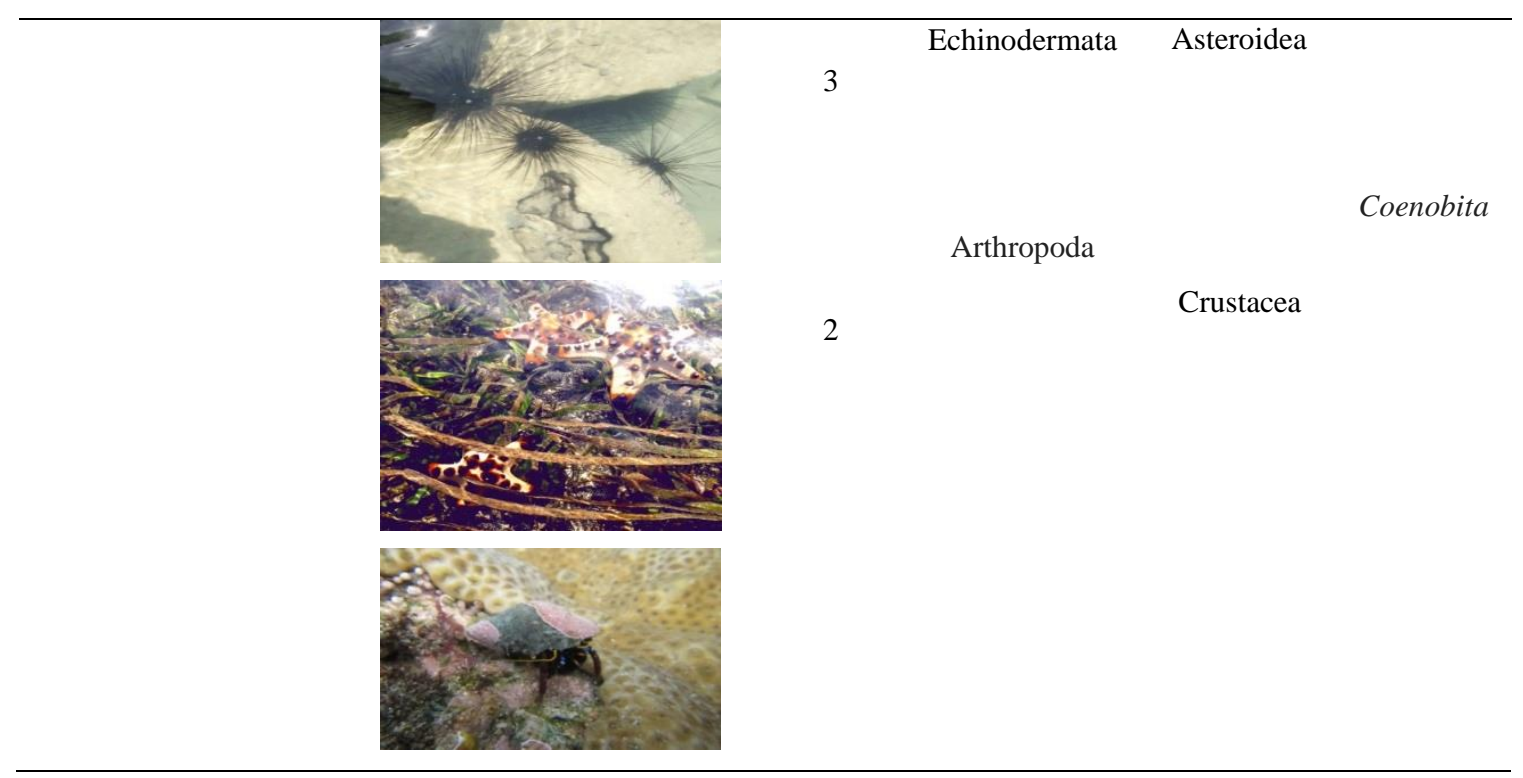

Berdasarkan hasil identifikasi di area Pantai Kecamatan Serasan ditemukan jenis hewan invertebrata dengan berbagai filum yaitu Molusca, Arthropoda, Coelenterata, dan Echinodermata. Adapun beberapa jenis class yang ditemui di Pantai Tanjung Setelung dan Pantai Tanjung Balau yaitu Bivalvia, Crustacea, Gastropoda, Anthozoa, Holothuroidea, Asteroidea, Ophiuroidea, dan Echinoidea.

Pada filum Anthropoda ditemukan sebanyak 5 jenis hewan yang masuk kelas Crustaceae, dan pada filum Anthopoda khususnya pada kelas Onychophora, Arachnoidea, Ohilopoda, Diplopoda, dan Insecta tidak temukan dalam penelitian. Hasil observasi pada filum Molusca terdapat kelas Bivalvia yang terdiri dari 5 jenis hewan yang ditemukan dan kelas Gastropoda terdapat 10 jenis hewan, dan filum Molusca kelas Amphineura, Scaphopoda, Pelecyoda tidak ditemukan dalam penelitian.

Filum Echinodermata pada kelas Astreoidea memiliki 2 jenis hewan, Ophiuroidea 1 jenis hewan, kelas Echinoidea terdapat 2 jenis hewan yang ditemukan, sedangkan filum Echinodermata khususnya pada kelas Crinoidea tidak ditemukan dalam penelitian. Dan terakhir adalah filum Coelenterata terdiri kelas Anthozoa ditemukan 1 jenis hewan, pada filum Coelenterata khususnya pada kelas Hydrozoa, Scypozoa, dan Acnidaria tidak ditemukan dalam penelitian. Banyaknya jenis hewan yang ditemukan di area Pantai Kecamatan Serasan bisa dapat dijadikan sebagai acuan dalam proses pembelajaran dengan memanfaatkan potensi lokal sebagai wadah tempat untuk mengkaitkan dalam materi invertebrata.

\subsection{Hasil Temuan Materi Ajar Biologi}

Berdasarkan hasil analisis kesesuain antar materi hasil observasidengan silabus dan RPP yang digunakan oleh guru pada materi animalia pada hewan invertebrata, di peroleh hasil sebagai berikut:

Tabel 4.1 Kesesuian Temuan Materi Invertebrata Berdasarkan Hasil Penelitian Di Area Pantai Kecamatan Serasan 


\begin{tabular}{|c|c|c|c|}
\hline Kompetisi Dasar & Indikator & $\begin{array}{c}\text { Tujuan } \\
\text { Pembelajaran }\end{array}$ & Keterangan \\
\hline $\begin{array}{l}\text { Mengelompokkan hewan } \\
\text { ke dalam filum } \\
\text { berdasarkan lapisan } \\
\text { tubuh, rongga tubuh, } \\
\text { simetris tubuh, dan } \\
\text { reproduksi }\end{array}$ & $\begin{array}{l}\text { Mendeskripsikan ciri-ciri } \\
\text { umum hewan } \\
\text { invertebrata (lapisan } \\
\text { tubuh, rongga tubuh, } \\
\text { simetris tubuh, dan } \\
\text { reproduksi) }\end{array}$ & $\begin{array}{l}\text { 1. Menentukan ciri- } \\
\text { ciri umum hewan } \\
\text { invertebrata }\end{array}$ & $\begin{array}{l}\text { Terpenuhi. Didasarkan } \\
\text { pada sistem morfologi, } \\
\text { bentuk yang memiliki } \\
\text { kerangka luar, dan } \\
\text { Tubuh invertebrata } \\
\text { dibagi menjadi tiga } \\
\text { bagian yaitu, kepala, } \\
\text { dada dan perut. Contoh } \\
\text { : kerang dan siput }\end{array}$ \\
\hline $\begin{array}{l}\text { Mengidentifikasi ciri dan } \\
\text { kompleksitas sistem dari } \\
\text { berbagai jenis hewan } \\
\text { invertebrata melalui } \\
\text { pengamatan objek/gambar } \\
\text { dan menyajikan dalam }\end{array}$ & & $\begin{array}{ll}2 . & \text { Menentukan daur } \\
& \text { hidup invertebrata }\end{array}$ & $\begin{array}{l}\text { Terpenuhi. Dilihat dari } \\
\text { tempat hidup hewan dan } \\
\text { cara memperoleh } \\
\text { makanan dan } \\
\text { reproduksi. Contoh : } \\
\text { kepiting }\end{array}$ \\
\hline & $\begin{array}{l}\text { Mengidentifikasi } \\
\text { klasifikasi animali }\end{array}$ & $\begin{array}{ll}\text { 3. } & \text { Menentukan } \\
\text { klasifikasi } \\
\text { invertebrata }\end{array}$ & 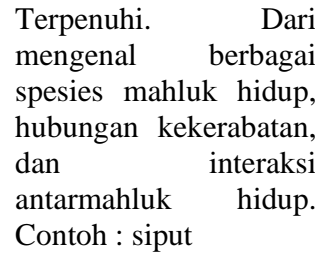 \\
\hline $\begin{array}{lr}\text { Menerapkan } & \text { prinsip } \\
\text { klasifikasi } & \text { untuk } \\
\text { mengelongkan } & \text { dalam } \\
\text { filum } & \text { berdasarkan } \\
\text { pengamatan anatomi dan } \\
\text { morfologi r serta } \\
\text { mengaitkan peranannya } \\
\text { dalam kehidupan }\end{array}$ & $\begin{array}{l}\text { Menjelaskan peran } \\
\text { hewan bagi kehidupan }\end{array}$ & $\begin{array}{ll}\text { 4. } & \text { Menentukan } \\
\text { peranan } \\
\text { invertebrata }\end{array}$ & $\begin{array}{l}\text { Terpenuhi. Berdasarkan } \\
\text { mamfaat dari hewan } \\
\text { invertebrata bagi } \\
\text { kehidupan baik sumber } \\
\text { pangan/makanan, } \\
\text { lingkungan dll. Contoh: } \\
\text { kepiting dan kerang } \\
\text { dapat dijadikan } \\
\text { makanan }\end{array}$ \\
\hline
\end{tabular}

\section{Pembahasan}

Pantai di area Kecamatan Serasan merupakan salah satu pantai yang memiliki potensi alam yang terdapat di Kelurahan Pelimpak. Potensi lokal di area Kecamatan Serasan meliputi SDA, manusia, budaya dan bisa digunakan serta dikembangkan untuk warga, pemerintah, dan pendidikan. Menurut Sarah (2014 :187) potensi daerah (lokal) merupakan potensi sumber daya spesifik yang dimiliki suatu daerah meliputi sumber daya alam, manusia, teknologi, dan budaya sehingga dapat dikembangkan untuk membangun kemandirian nasional.

Pada lokasi Pantai Tanjung Balau dan Pantai Tanjung Setelung di Kecematan Serasan memiliki potensi sumber daya alam laut yang dapat dimanfaatkan sebagai tempat atau lokasi yang dapat dijadikan oleh guru dan siswa untuk menunjang proses pembelajaran mata pelajaran biologi khususnya mata pelajaran invertebrata. Hal ini sejalan dengan Asri,Widowati (2012:7) Dalam pemamfaatan lingkungan sekitar sebagai pembelajaran, kehadiran potensi lokal mempunyai arti yang cukup penting, karena dalam kegiatan tersebut ketidakjelasan bahan yang disampaikan dapat dibantu dengan menghadirkan potensi lokal 
sebagai penyalur pesan guna mencapai tujuan pembelajaran invertebrata, tidak memerlukan waktu yang lama jika dimamfaatkan secara efektif. Beberapa filum ada yang tidak dikaji dalam penelitian misalnya pada filum Platyhelminthes, filum Nemathelminthes, filum Protozoa, filum Porifera, filum Ctenophora, dan filum Annelida tidak ditemukan dalam riset.

Berdasarkan hasil temuan materi ajar biologi yang dikaitkan dengan hasil observasi hewan invertebrata di area Pantai Kecamatan Serasan dapat mencapai indikator dan tujuan pembelajaran disilabus dan disajikan pada Tabel 4.2. Berdasarkan hasil tersebut ditemukan konsep pembelajaran, yaitu: Mendeskripsikan ciri-ciri umum hewan invertebrata (lapisan tubuh, rongga tubuh, simetris tubuh, dan reproduksi), mengidentifikasi klasifikasi animalia, daur hidup, dan menjelaskan peran hewan bagi kehidupan. Akan tetapi tidak semua konsep pembelajaran terpenuhi dalam hasil temuan materi, minsalnya ciri-ciri hewan vertebrata, klasifikasi hewan vertebrata, daur hidup, dan peranan vertebrata bagi kehidupan. Hal ini karena penelitian fokus pada temuan jenis-jenis hewan invertebrata yang dijumpai di area Pantai Kecamatan Serasan, sehingga materi yang ditemukan hanya mendukung materi animilia (hewan Invertebrata).

Kurikulum yang digunakan di SMAN 1 Serasan dan SMAN 1 Serasan Timur adalah kurikulum 2013. Perangkat pembelajaran IPA pada meteri invertebrata masih banyak dilakukan didalam kelas, hal ini disampaikan dalam wawancara dengan guru IPA di SMA. Kondisi ini menyebabkan pembahasan terhadap materi invertebrata cenderung kurang mendalam dan siswa terbatas untuk mengamati dan mencoba sesuatu yang di luar, serta siswa lebih banyak diberitahu tentang materi oleh guru dikelas di banding mencari tahu sendiri, sehingga akan mengurangi siswa dalam berkreativitas. Menurut Kemdikbud (2014:43) didalam kurikulum 2013 adanya proses pembelajaran yang mendukung tentang kreativitas siswa dalam observing (mengamati) dan experimenting (mencoba) dan menuntun siswa untuk mencari tahu, bukan diberitahu (discovery learning).

Pada kurikulum 2013 dalam proses pembelajaran siswa dituntut untuk aktif sehingga lebih efektif dan tidak hanya menjadi pendengar saja dikelas dan guru juga harus dapat merubah pembelajaran yang bersifat ceramah serta mengaktualisasikan kemampuan siswa menuju ke proses belajar sendiri atau melakukan aktivitas sendiri kepada siswa. Hal ini bisa dilakukan dengan mengkaitkan pembelajaran dengan pemamfaatan potensi lokal yang ada di area Pantai Kecamatan Sersasan. Menurut Rusman (2011:323) Pembelajaran yang efektif dapat mengaktualisasikan kemampuannya di dalam dan di luar kelas. Hal serupa juga disampaikan oleh Hamalik (2011:171), yang menyatakan bahwa: "pembelajaran yang efektif adalah pembelajaran yang menyediakan kesempatan kepada siswa untuk dapat belajar sendiri atau melakukan aktivitas sendiri”.

Pembelajaran yang menggunakan observasi dengan memanfaatkan potensi lokal sebagian diminati siswa di SMAN 1 SERASAN dan SMAN 1 SERASAN TIMUR. Mereka rata-rata meninginkan adanya inovasi dalam proses pembelajaran, hal ini disampaikan pada wawancara siswa. Namun, guru disekolah dapat hambatan karena kurang waktu pembelajaran dan guru belum pernah untuk memcoba pembelajaran diluar sekolah khususnya pembelajaran dengan pemanfaatan potensi lokal, dapat dilihat dari hasil wawancara dengan guru di sekolah tersebut. Hal ini disebabkan belum adanya acuan untuk melaksanakan program tersebut sehingga mereka memerlukan adanya acuan atau panduan yang dapat menjadi petunjuk pelaksanaan strategi pembelajaran itu. Selain itu, di sekolah 
juga belum terdapat dokumen-dokumen yang dapat memandu pembelajaran yang menggunakan teknik observasi lingkungan dengan memamfaatkan potensi lokal. Padahal, menurut Morisson, Ross, dan Kemp (2001), desain sistem pembelajaran akan membantu pendidik sebagai perancang program atau pelaksana kegiatan pembelajaran dalam memahami kerangka teori lebih baik dan menerapkan teori tersebut untuk menciptakan aktivitas pembelajaran yang lebih efektif, efesien, produktif, dan menarik.

Penggunaan potensi lokal di Pantai Tanjung Setelung dan Pantai Tanjung balau dapat membantu pemahaman siswa terhadap pelajaran invertebrata yang bersifat abstrak. Potensi lokal juga dapat memperjelas dalam penyampain materi yang disampaikan dalam menampilkan hewan secara nyata. Pembelajaran dengan menggunakan potensi lokal juga dapat melatih cara berpikir siswa dengan mengkongkritkan suatu abstrak pada materi invertebrata yang selalu berkaitan dengan menampilkan gambar hewan. Pemamfaatan potensi lokal di Pantai Tanjung Balau dan Pantai Tanjung Setelung dalam proses pembelajaran akan lebih bermakna karena siswa dihadapkan dengan peristiwa yang bersifat aktual dan alami yang dapat dipertanggung jawabkan kebenarannya. Menurut Asri (2012:712) Pemanfaatan lingkungan sekitar di dalam proses pembelajaran Biologi akan lebih bermakna karena siswa dihadapkan pada peristiwa yang bersifat aktual dan alami yang dapat dipertanggungjawabkan kebenarannya.

Pembelajaran diluar kelas membuat siswa berinteraksi langsung dengan lingkungan, membuat proses pada pembelajaran lebih menyenangkan. Siswa dapat melihat hewan secara nyata, mendengar, merasakan bentuk tubuh hewan dengan meraba, dan siswa dapat mencium bau hewan invertebrata yang ditemui. Dengan ini membuat siswa lebih paham dengan materi dan tujuan pembelajaran melalui benda-benda yang ditemui secara langsung. Menurut Riza, Fazariah (2015:40-156) suatu kegiatan di luar kelas atau luar sekolah yang membuat pembelajaran menjadi lebih menarik dan menyenangkan, bisa dilakukan di manapun dengan menekankan pada proses belajar berdasarkan fakta nyata, yang materi pembelajarannya dapat secara langsung dialami melalui kegiatan pembelajaran secara langsung. Selain itu kegiatan di luar kelas dengan melihat benda nyata di luar lapangan atau lingkungan menjadikan materi yang dipelajari menarik dan tidak membosankan oleh siswa serta hasil belajar pada siswa dapat ditingkatkan. Hal ini sejalan dengan Sri (2015:17-92) pembelajaran di luar dengan melihat benda nyata mengakibatkan adanya kegiatan belajar yang lebih menarik dan tidak membosankan sehingga hasil belajar siswa dapat ditingkatkan. Hasil wawancara dengan guru dan siswa, guru jarang bahkan tidak pernah mengajak siswa untuk belajar di luar kelas khususnya pada pembelajaran hewan invertebrata. Padahal dengan mengajak siswa belajar diluar kelas akan berdampak lebih panjang pada meningkatkan ketertarikan siswa terhadap pembelajaran. Karena siswa dapat mengamati, mendengar, dan merasakan fenomena yang terjadi di lingkungan secara langsung. Hal ini sejalan dengan Riri Astuti (2015) pembelajaran di luar kelas akan berdampak lebih panjang pada siswa, karena dengan mengamati, mendengar, dan merasakan secara langsung fenomena yang terjadi di lingkungan akan meningkatkan ketertarikan siswa terhadap pembelajaran. Potensi lokal bukan hanya untuk pemanfaatan proses belajar saja, tetapi bisa dimanfaatkan dalam hal objek wisata, dan sarana perekonomian penduduk setempat berdasarkan hasil wawancara dengan dinas perikanan.

Dalam proses pembelajaran alam di pantai siswa dapat juga berperan dalam mengembangkan potensi sumber daya lokal daerah sendiri dan membelajarkan tentang 
bagaimana pemanfaatan dan pelestariannya. Pembelajaran ini juga mendorong terbentuknya sikap positif tentang potensi lokal setempat sehingga dapat memotivasi siswa untuk belajar dan mengembangkan keterampilan sesuai potensi lokal. Di lokasi Pantai di area Kecamatan Serasan ditemukan hewan asli yang tinggal didaerah pantai tersebut dan dapat dioptimalkan dalam berbagai pemamfaatan pembelajaran bagi siswa dan guru serta dapat melihat permasalahan lingkungan di sekitar daerah pantai dan mengambil tindakan dalam masalah tersebut. Menurut Mumpuni et al (2013:52-57) bahwa bentuk pengintegrasian materi pembelajaran yang sesuai dengan isu-isu lingkungan sekitar dapat memberikan kemudahan bagi para peserta didik dalam menyelesaikan permasalahan-permasalahan lingkungan. Penjelasan diatas dapat diartikan bahwa pembelajaran berbasis potensi lokal mampu menjadi sarana siswa untuk pembelajaran kontekstual, pemanfaatan dan pelestarian potensi lokal dilingkungan sekitar.

\section{KESIMPULAN DAN SARAN}

\section{Kesimpulan}

Berdasarkan data hasil penelitian dapat disimpulkan bahwa:

1. Potensi lokal hewan Invertebrata di area Pantai Kecamatan Serasan sesuai dengan tujuan pembelajaran materi Invertebrata (Animalia) pada kelas X yaitu Menentukan Ciri-ciri Umum Hewan Invertebrata (lapisan tubuh, rongga tubuh, simetris tubuh, dan reproduksi); Menentukan Daur Hidup Invertebrata; Menentukan Klasifikasi Invertebrata; menentukan Peranan Invertebrata (menjelaskan peranan hewan bagi kehidupan).

2. Potensi lokal hewan Inveretebrata di area Pantai Kecamatan Serasan berpotensi sebagai tempat proses pembelajaran Biologi SMA.

\section{Saran}

Berdasarkan hasil analisis mengenai kesesuaian materi hasil temuan dengan materi tuntutan kurikulum serta dampak potensi lokal bagi siswa dapat diketahui sebagian beberapa materi tidak ditemukan dalam penelitian. Hal ini menjadi peluang untuk dilakukan penelitian lebih lanjut terhadap materi yang belum pernah dilakukan dalam riset. Harapannya semua materi akan terpenuhi dan sesuai dengan tuntutan kurikulum. Meskipun demikian, secara keseluruhan isi materi dapat dikatakan sudah cukup terpenuhi karena sifatnya yang spesifik pada subpokok bahasan tertentu.

\section{DAFTAR RUJUKAN}

Aditiawati, Pingkan, dkk. (2016.) Pengembangan Potensi Lokal Di Desa Panawangan Sebagai Model Desa Vokasi Dalam Pemberdayaan Masyarakat Dan Peningkatan Ketahanan Pangan Nasional. Jurnal Sosioteknologi. 15(1): 59-67.

Asri Widowati, (2008). Brainstorming Sebagai Alternatif Pengembangan Berfikir Kreatif Dalam Pembelajaran Sains Biologi. Tesis. Yogyakarta: Program Pascasarjana UNY.

Asri Widowati, (2012). Optimalisasi Potensi Lokal Sekolah Dalam Pembelajaran Biologi Berbasis Kontruktivisme. Jurnal Pendidikan. Hal: 7-13. 
Bitta, pegawati. 2005. Identifikasi Potensi dan Pemetaan Sumberdaya Pesisir Pulau - Pulau Kecil dan Laut Kabupaten Natuna - Provinsi Kepulauan Riau.vol.10 hal :229-236

Dahuri et.al. 1996. Pengelolaan Sumberdaya Wilayah Pesisir dan Lautan secara terpadu.

Hamalik, oemar, (2013). Proses Belajar Mengajar. Jakarta: Bumi Aksara

Kemdikbud, (2013). Konsep dan Implementasi Kurikulum 2013. Hal: 43

Lestari, Very dan Hadi Sasongko. (2014). Keanekaragaman Jenis Suku Leguminosae di Kawasan Plawangan Taman Nasional Gunung Merapi Sebagai Alternatif Sumber Belajar Biologi Siswa SMA Kelas X. JUPEMASI-PBIO. 1(1): 129-132.

Purnomo, Dwito, Meti Indrowati, Puguh Karyanto. (2013). Pengaruh Penggunaan Modul Hasil Penelitian Pencemaran Di Sungai Pepe Surakarta Sebagai Sumber Belajar Biologi Pokok Bahasan Pencemaran Lingkungan Terhadap Hasil Belajar Siswa. Pendidikan Biologi. 5(1): 59-69.

Riri Astuti, (2015). Pengembangan Pembelajaran Di Luar Kelas Melalui Project Based Learning Dalam Meningkatkan Keterampilan Berpikir Kreatif Pada Materi Penangganan Limbah. Jurnal Pendidikan. Hal: 2-34.

Riza Fazariah, (2015) Pengaruh Penggunaan Metode Pembelajaran Outdoor Learning Terhadap Motivasi Belajar Siswa Kelas Iii Dalam Pembelajaran Ilmu Pengetahuan Sosial (Ips) Di Madrasah Ibtidaiyah Nurul Huda Pondok Karya Tangerang Selatan. Jurnal Penelitian. Hal: 18-156.

Rusman. (2011:323). Model-model Pembelajaran. Bandung: Rajawali Pers

Sarah, Siti, Maryono. (2014). Pengembangan Perangkat Pembelajaran Berbasis Potensi Lokal Untuk Meningkatkan Living Values Peserta Didik Sma Di Kabupaten Wonosobo. Jurnal Teknologi Technoscientia. 6(2): 185-194.

Situmorang, Risya Pramana. (2016). Analisis Potensi Lokal Untuk Mengembangkan Bahan Ajar Biologi Di Sma Negeri 2 Wonosari. Jurnal Pendidikan Sains. 4(1): 51-58.

Sri Nur Indahsari. (2015). Perbandingan Antara Pembelajaran Di Luar Kelas Dan Kegiatan Pembelajran Di Dalam Kelas Terhadap Hasil Belajar Matematika Siswa Kelas VII SMP NEGERI 2 TURETEA KAB.JENEPONTO

Yokhebed, Titin, dan Eko Sri Wahyuni. (2016). Peningkatan Life Skill melalui Pembelajaran berbasis Keunggulan Lokal. Proceeding Biology Education Conference. (ISSN: 2528-5742). 13(1) : 455-460. 